\title{
VRTOVI ODGOJNO-OBRAZOVNIH INSTITUCIJA NA PODRUČJU GRADSKE ČETVRTI SESVETE
}

\author{
GARDENS OF EDUCATIONAL INSTITUTIONS IN THE AREA \\ OF THE CITY DISTRICT OF SESVETE
}

\author{
Vesna Židovec, Tea Pirić, Martina Skendrović Babojelić, \\ Dubravka Dujmović Purgar
}

\section{SAŽETAK}

Uz sve funkcije koje imaju zelene površine, školski vrt ima još i edukativnu ulogu. Nekad je bio vezan uz škole u ruralnom području, dok danas postoje brojne potvrde o njegovoj važnosti u obrazovnom procesu bez obzira radi li se o ruralnom ili urbanom okruženju. Gradska četvrt Sesvete cijelim je svojim područjem smještena izvan granica grada Zagreba kao naselja. Zauzima čak četvrtinu njegovog ukupnog prostora na sjeveroistoku grada. Još prije nekoliko desetljeća najveći je dio tog prostora obilježavao izrazito ruralni način života, elementi kojega su i danas jasno vidljivi u većini ovdašnjih naselja. Industrijalizacija i s njom povezano doseljavanje tisuća novih stanovnika ponajprije su, već sredinom šezdesetih godina prošlog stoljeća, potaknuli brzu urbanizaciju tada još malih Sesveta i drugih tadašnjih samostalnih naselja. Na cijelom području postoje 4 gradske i 5 privatnih predškolskih ustanova te osam osnovnih škola. Neke od tih institucija imaju vrt koji je uključen u obrazovni program sa svrhom razvoja pozitivnih psihofizičkih osobina kod učenika. Cilj rada bio je istražiti postojanje vrtova uz odgojno-obrazovne institucije (predškolske TIP 1 i osnovnoškolske TIP 2) na području gradske četvrti Sesvete, identificirati biljne svojte prema kategorijama (jedno- i dvogodišnje cvjetne vrste, trajnice i geofiti, grmlje, drveće i penjačice); procijeniti uređenost vrtova i njihovu usklađenost s tradicijom i prostorom u kojem se nalaze.

U vrtovima TIP 1 zabilježeno je ukupno 97 svojti (44 jedno- i dvogodišnje, 12 trajnica i geofita, 15 grmova i 26 stabala), a u vrtovima TIP 2 ukupno 40 svojti ( 8 jedno- i dvogodišnje, 7 trajnica i geofita, 19 grmova i 6 stabala). Osim jednog vrtića, niti jedna od istraživanih odgojno-obrazovnih institucija na području gradske četvrti Sesvete nisu imala vrt uključen u odgojno-obrazovni rad.

Ključne riječi: hortikulturna terapija, ekologija, edukacija, inventarizacija, škola i vrtić 
Vesna Židovec i sur.: Vrtovi odgojno-obrazovnih institucija na području gradske četvrti Sesvete

\begin{abstract}
With all the functions that green surfaces have, the school garden has an educational role as well. It was once related to schools in the rural area, while today there are numerous confirmations of its importance in the educational process, whether rural or urban. The city district of Sesvete is entirely in its area located outside the city limits of Zagreb as a settlement. It occupies as much as a quarter of its total area in the northeast of the City. A few decades ago, most of this area marked the rural way of life, elements that are still clearly visible today in most of the local settlements. Industrialization and the associated immigration of thousands of new inhabitants were, in the mid-sixties of the last century, prompted by the rapid urbanization of the then small Sesvete and other then independent settlements. There are 4 urban and 5 private pre-school institutions and several primary schools throughout the area. Some of these institutions have a garden that is included in the educational program for the purpose of developing positive psychophysical traits in students and helps to acquire new knowledge and skills in a healthy environment. The aim of the study was to investigate the existence of gardens with educational institutions (pre-school TYPE 1 and elementary school TYPE 2) in the area of Sesvete, to identify plant taxa by categories (annuals, biennials, perennials and geophytes, shrubs, trees and climbers); to evaluate the maintenance of the gardens and their conformity with the tradition and the area in which they are located.

In TYPE 1 gardens, a total of 97 species (44 annuals and biennials, 12 perennials and geophytes, 15 shrubs and 26 trees) were recorded, and in TYPE 2 gardens 40 species ( 8 annuals and biennials, 7 perennials and geophytes, 19 shrubs and 6 trees). In addition to a kindergarten, none of the surveyed educational institutions in the area of the city district of Sesvete had a garden included in the educational work.
\end{abstract}

Key words: horticultural therapy, ecology, education, inventarization, school and kindergarten

\title{
UVOD
}

Zelenii prostori u mjestu imaju višestruko značenje, kako s aspekta raščlambe, funkcije, karaktera i organizacije prostora, tako i s aspekta socijalne, zdravstvene, psihološke i kulturološke svrhovitosti. To govori o vrlo složenoj namjeni zelenih prostora u naseljima, o njihovu dubljem značenju i smislu, a ne samo o tzv. dekorativnoj funkciji (Šišić, 2011.). 
Vesna Židovec i sur.: Vrtovi odgojno-obrazovnih institucija na području gradske četvrti Sesvete

Ozelenjivanje gradova direktno smanjuje ekološki otisak urbane populacije: pored lokalno proizvedene hrane koristi su uočljive i kroz upijanje gradskog zagađenja i emisije ugljičnog dioksida, smanjenje lokalnog utjecaja zagrijanog zraka, pročišćavanje vode i tla (Butorac i Šimleša, 2007.).

Zabilježen je pozitivan utjecaj zelenila na ljudsko zdravlje od iskustva i interakcije ljudi s prirodom (Katcher i Beck, 1987.; Kaplan i Kaplan, 1989.; Irvine i Warber, 2002.; Maller i sur., 2005.), brži oporavak nakon bolesti (Ulrich, 1984.), općenito bolje zdravstveno stanje (Stilgoe, 2001.; de Vries i sur., 2003.; Maas i sur., 2006.), dugovječnost (Takano i sur., 2002.), oslobađanje od stresa (Moore, 1981.; Leather i sur., 1998.; Parsons i sur., 1998.; Stigsdotter i Grahn, 2004.), smanjen mentalni umor (Hartig i sur., 1991.; Kuo, 2001.), mogućnosti promišljanja (Herzog i sur., 1997.; Fuller i sur., 2007.), udio socijalne interakcije (Sullivan i sur., 2004.), pa do smanjenja postotka kriminala (Kuo i Sullivan, 2001.).

Slično tomu, nedostatak zelenila povezan je s višom razinom depresije i anksioznosti (Macintyre i sur., 2003.), prema (Davies i sur., 2009.). U tom smislu je prepoznata terapijska uloga vrtlarenja i hortikulture.

Hortikultura kao terapija predstavlja neformalni terapijski učinak. Terapijska hortikultura označava različite prakse kojima se formalizira imanentni terapijski potencijal vrta i vrtlarenja više ili manje strukturiranim aktivnostima vrtlarenja. $U$ istom se značenju koristi termin hortikulturna terapija (Dujmović, 2016.).

Prema Dujmoviću (2016.) znanstvena istraživanja na različitim skupinama korisnika potvrdila su sljedeće dobrobiti terapijske hortikulture i terapijskih vrtova na psihičko zdravlje: poboljšanje dobrog osjećanja (well-being) (Ulrich i Parsons, 1992.; Galindo i Rodrieguez, 2001.; Kaplan, 2001.; Jarrott i sur. 2002.; Barnicle i Stoelzle Midden, 2003.; Hartig, 2003.), poboljšanje kvalitete života (Willets i Sperling, 1983.; Waliczek i sur., 1996.), poboljšanje raspoloženja (Whitehous i sur., 2001.), ublažavanje depresije (Relf, 1978.; Mooney i Milstein, 1994.; Cooper Marcus i Barnes, 1999.), smanjenje doživljaja stresa (Ulrich i sur., 1991.; Rodiek, 2002.), jačanje osjećaja samokontrole (Relf i sur., 1992.); poboljšanje društvenog zdravlja: poboljšanje društvene interakcije (Langer i Rodin, 1976.; Moore, 1976.; Perrins-Margalis i sur., 2000.), poboljšanje integracije u društvo (Kweon i sur., 1998.), poboljšanje grupne kohezije (Bunn, 1986.), razvijanje zdravih obrazaca društvenog funkcioniranja (Langer i Rodin, 1976.; Kuo i sur., 1998.); poboljšanje duhovnog zdravlja; 
Vesna Židovec i sur.: Vrtovi odgojno-obrazovnih institucija na području gradske četvrti Sesvete

stjecanje znanja, vještina i vrlina - vrtlarenjem se njeguju odgovornost, inicijativnost, samopouzdanje (Moore, 1989.; Blair i sur., 1991.; Feenstra i sur., 1999.), timski rad, strpljivost, optimizam, pamćenje (Wells, 2000.) i koncentracija (Taylor i sur., 2001.; Namazi i Haynes, 1994.).

Formalno, terapijski vrtovi su posebno dizajnirani vrtovi s ciljem jačanja motoričkih, senzoričkih, kognitivnih, afektivnih, alimentarnih, duhovnih i socijalnih potencijala za skladan život i zdravlje. Terapijski vrtovi i terapijska hortikultura omogućuju svakom ljudskom biću, bez obzira na ograničenja, da radi, stječe nova znanja i opušta se (Dujmović, 2016.).

Školski vrtovi imaju također terapijski učinak. Prema Muehlhoffu i Boutrifu (2010.) školski vrtovi upućuju djecu kako uzgojiti različitu hranu: povrće, voće, mahunarke, male životinje sa sviješću o zdravoj hrani (hortikultura, poljoprivreda, znanost); pokazuju djeci i njihovim obiteljima kako proširiti i poboljšati prehranu namirnicama iz vlastitog uzgoja; povećavaju sklonost djece konzumaciji svježeg povrća i voća; obogaćuju školske obroke mikronutirijentima porijeklom iz povrća i voća (nutricionizam i zdravlje); promoviraju i ponovno uvode hortikulturne vještine u gospodarstva ovisna o poljoprivredi; potiču poduzetničke vještine na području tržno orjentiranog vrtlarenja (gospodarske vještine, upravljanje, marketing); povećavaju svjesnost o potrebi zaštite okoliša i očuvanja tla (očuvanje okoliša).

Vrtovi su prava, ponekad i jedina mjesta, gdje djeca mogu naučiti: uspješno uzgojiti hranu, poštovati okoliš kroz neposrednu aktivnost (npr. očuvanje vode, nadomještanje stabala), uočiti vezu između vrtarenja i dobre prehrane, naučiti što je zdrava prehrana, vrednovati svježe povrće, voće, mahunarke, uključujući domaću hranu, skladištiti i čuvati hranu te ju pripremati na ispravan način, uvažiti vezu između prehrane i zdravlja, primjenjivati koncepte dobre prehrane $\mathrm{i}$ zdravog načina života, oduprijeti se lošoj hrani, objasniti i predstaviti drugima vlastito učenje i razumijevanje (Muehlhoff i Boutrif, 2010.).

Školski su se vrtovi u povijesnom razvoju mijenjali, dobivali novu kvalitetu i obilježja (Munjiza, 2003.). Schwab (1877.) piše o razvoju školskih vrtova te navodi da je Locke u Engleskoj smatrao još u 17. stoljeću kako se sinovi otmjenijih obitelji trebaju podučavati vrtlarstvu, Francke (1706.) je naveo kako se 'pitomci njegova zavoda za prostih satih bave i vrtljarstvom', a Pestalozzi (18. stoljeće) zahtijevao da se mladež bavi poslovima na polju i u vrtu. U početku su školski vrtovi bili svojevrsni botanički vrtovi, koji su predstavljali izvor zornosti u nastavi i mjesto školskih šetnji i izleta. Kasniji zadatak školskih 
Vesna Židovec i sur.: Vrtovi odgojno-obrazovnih institucija na području gradske četvrti Sesvete

vrtova je osiguravanje praktičnog rada za nastavu gospodarstva pod različitim nazivima. Krajem 19. i u 20. stoljeću pred školske vrtove postavlja se isključivi zadatak proizvodnje i oni dobivaju gospodarsko-proizvodni karakter (Munjiza 2003.). Prema Schwabu (1877.) carica Marija Terezija, utemeljiteljica pučkih škola u austrougarskoj državi, dana 6. prosinca 1774. izdaje školski zakon prema kojem se 'mladež u pučkih školah podučava i u gospodarstvu'. U uvodnom dijelu zaključuje: 'dokazalo se da su školski vrti isto tako potrebni za preparandije, realke, gimnazije, kao što i za pučke škole (obće i gradjanske). Dobro uredjen školski vrt ne smije manjkati ni kod nijednoga zabavišta ni čuvališta malene djece.'. Isti autor ističe: 'Školski vrt mora kao odgojno i nastavno sredstvo biti uza svaku pučku školu uredjenu prema duhu vremena.'.

Poslije II. svjetskog rata školski se vrtovi uglavnom asimiliraju u učeničke zadruge (Munjiza, 2003.). Skulj (1954.) ističe da 'pravilno izvedeni školski vrtovi nisu samo ukras školi i lokalnoj sredini već i ogledna postaja za voćarstvo, povrtlarstvo, pčelarstvo, a u vinorodnih krajeva i vinogradarstvo'.

U suvremenim uvjetima, školski vrtovi, imaju botanički, proizvodni, opće nastavni karakter. Naglasak je na sustavnom praćenju, postavljanju pokusa, istraživačkom radu; ekopokretu i uzgoju ekološki čiste hrane; profesionalnom informiranju i usmjeravanju; ali i psihoterapeutskoj ulozi rada. To je mjesto poticanja suradničke, međuljudske komunikacije, aktivnog slušanja, vještine ugrožene udaljavanjem ljudi pretjeranom upotrebom tehnike (Munjiza, 2003.). Tako Vladimir (1998.) ističe da su najčešće aktivnosti u školskom vrtu koje pridonose socijalizaciji: usvajanju novih znanja i vještina; aktivnosti u školskom vrtu koje se temelje na suradnji; motiviranost učenika; usvajanje estetskih vrijednosti; zadovoljavanje tjelesnih potreba za kretanjem i aktivnošću; te ostvarivanje kontakta djece s prirodom.

Gradska četvrt Sesvete posljednjih se 50 godina znatno urbanizirala, dijelom u smislu izgradnje centra gradske četvrti, a više načinom života prigradskih naselja čija osnovna djelatnost više nije isključivo poljoprivreda. Posljednji veliki val doseljavanja bilježi se u vrijeme Domovinskog rata. Na cijelom području postoje četiri gradske i pet privatnih predškolskih ustanova te osam osnovnih škola, pri čemu i neki vrtići i pojedine škole djeluju na više lokacija kao područne škole. Neke od tih institucija imaju vrt koji bi mogao biti uključen u obrazovni program sa svrhom razvoja pozitivnih psihofizičkih osobina kod učenika. 
Vesna Židovec i sur.: Vrtovi odgojno-obrazovnih institucija na području gradske četvrti Sesvete

Cilj rada bio je istražiti prisutnost i veličinu vrtova uz odgojno-obrazovne institucije na području gradske četvrti Sesvete, identificirati biljne svojte prema kategorijama (jedno- i dvogodišnje cvjetne vrste, trajnice i geofiti, grmlje, drveće i penjačice); procijeniti uređenost vrtova i njihovu usklađenost $\mathrm{s}$ tradicijom i prostorom u kojem se nalaze.

\section{MATERIJAL I METODE}

Terensko istraživanje provedeno je na području gradske četvrti Sesvete u vrtovima šest predškolskih i četiri osnovnoškolske ustanove u razdoblju od travnja 2013. do svibnja 2014. godine.

Gradska četvrt Sesvete cijelim je svojim područjem smještena izvan granica grada Zagreba kao naselja. Zauzima čak četvrtinu ukupnog prostora Grada Zagreba na njegovu sjeveroistočnom dijelu s površinom od $165,255 \mathrm{~km}^{2}$. Na zapadu se naslanja na gradske četvrti Gornja i Donja Dubrava, a na jugu na Peščenicu - Žitnjak. Na istoku graniči sa Zagrebačkom, a na sjeveru s Krapinsko-zagorskom županijom. Osim naselja gradskog karaktera, Sesvete obuhvaćaju još 36 manjih samostalnih naselja (Grad Zagreb). Geografski, Sesvete su smještene na 45\%49'39" sjeverne geografske širine i $16^{\circ} 6^{\prime} 42^{\prime \prime}$ istočne geografske dužine. Nadmorska visina Sesveta kreće se od 200 do $400 \mathrm{~m} / \mathrm{nm}$.

Istraživanjem su obuhvaćene sljedeće odgojno-obrazovne institucije:

1. Predškolske ustanove (TIP 1):

1.1. DV A: privatni dječji vrtić, otvoren 2006. godine, danas djeluje u okviru pet odgojnih skupina, dvije jasličke i tri vrtićke odgojne skupine. Vanjski dvorišni prostor je ograđen, ozelenjen i opremljen spravama za motoričke aktivnosti te pruža sigurne i poticajne uvjete za boravak djece na zraku. Sastoji se od četiri dijela: igralište sa spravama, prostor za igru u sjeni drveća, povrtnjak (o kojem brigu vode djeca $\mathrm{i}$ odgojiteljice) te multifunkcionalni sportski teren $\mathrm{s}$ umjetnom travom.

1.2. DV B: privatni dječji vrtić u centru Sesveta (godina otvaranja nepoznata). Prostor je uređen $\mathrm{s}$ namjenom ispunjavanja osnovnih zadaća dječjeg vrtića kao ustanove za ostvarivanje organizirane njege, odgoja, obrazovanja i zaštite djece do polaska u osnovnu školu. Objekt je udaljen od glavnih, velikih prometinca, proizvodnih pogona, 
Vesna Židovec i sur.: Vrtovi odgojno-obrazovnih institucija na području gradske četvrti Sesvete

parkirališnih gradskih površina. Smješten je na ozelenjenoj površini, uz mirnu zonu stanovanja. Sastoji se od ozelenjene, igrališne površine koja je na ravnoj i osunčanoj (južnoj) strani. Uz klupice za djecu, obogaćen je pješčanikom sa suhim pijeskom i ljuljačkama za djecu. Posebno je odijeljen dio igrališta za jasličku skupinu, koji se nalazi na travnatoj površini i također je obogaćen pješčanikom i ljuljačkama.

1.3. DV C: gradski dječji vrtić u naselju Jelkovec. Matični objekt otvoren je u svibnju 2009. godine s kapacitetom 20 skupnih jedinica. Suvremeno je arhitektonski dizajniran i opremljen: u matičnom objektu su dvije polivalentne dvorane - jedna za djecu od 1 - 3 god., a druga za djecu od 3 - 7 godina. Matični objekt ima bazen, igralište, likovni atelje, istraživački atelje i dva prostora za istraživanje svjetla. Područni objekt otvoren je u siječnju 2010. godine, ima kapacitet devet odgojnih skupnih jedinica; suvremeno je dizajniran i opremljen dvoranom za motoričke aktivnosti.

1.4. DV D: gradski vrtić u kojem se realizira odgojno obrazovni rad s djecom rane i predškolske dobi: u redovitom programu u 23 odgojne skupine na četiri lokacije i u programu predškole u dvije odgojne skupine djece u godini pred polazak u osnovnu školu na dvije lokacije u kojima je ukupno 28 djece.

1.5. DV E: najstariji vrtić na području Sesveta s tradicijom dužom od 50 godina, djeluje u 30 odgojnih skupina na šest lokacija.

1.6. DV F: gradski dječji vrtić, razvija se od 2007. godine, a u programu ima 33 odgojne skupine u redovnom i obogaćenim desetsatnim programima te pet odgojnih skupina u programu predškole na šest lokacija.

2. Osnovne škole (TIP 2):

2.1. TIP 2 A: osnovana je 1975. godine, a danas brine o 860 učenika u 38 razrednih odjeljenja.

2.2. TIP 2 B: datira još od 1926. godine, djeluje na pet dislociranih lokacija unutar Gradske četvrti Sesvete, brine o 609 učenika u 33 razredna odjela.

2.3. TIP 2 C: suvremena škola osnovana 2007. godine, radi s 28 razredna odjela. 
Vesna Židovec i sur.: Vrtovi odgojno-obrazovnih institucija na području gradske četvrti Sesvete

2.4. TIP 2 D: jedna je od najstarijih škola Hrvatskog Prigorja, osnovana još 1836. godine. Godine 2009. proglašena je Međunarodnom eko školom te u suradnji s udrugom Lijepa naša radi na poticanju ekološke svijesti među učenicima, učiteljima, ostalim zaposlenima u školi, ali i u cjelokupnoj lokalnoj zajednici. Detaljan plan djelovanja eko škole dostavlja udruzi Lijepa naša.

Terenski rad na snimanju flore započeo je u travnju 2013. godine, a završio u svibnju 2014. U tom razdoblju svaki je vrt višekratno posjećen te su zabilježene sve biljne vrste. Određivanje vrsta, taksonomske pripadnosti i porijekla utvrđeno je pomoću literature Domac (2002.), Erhardt i sur. (2014.), Idžojtić (2009.).

Prikupljenim podacima napravljen je prijedlog odabira biljnih vrsta za sadnju tradicionalnog vrta u sklopu navedenog doma koja bi se mogla koristiti i na drugim sličnim lokacijama.

Biljni materijal razvrstan je prema sljedećim kategorijama: jedno- i dvogodišnje cvjetne vrste, trajnice i geofita, grmlje, drveće, drvenaste penjačice. Biljne vrste su također procijenjene prema utilitarnosti na: utilitarne (voćne, povrtne vrste, ljekovito i začinsko bilje) te ukrasne. Neke vrste imaju dvojni karakter, ukrasni ili utilitarni, a s obzirom na njihovu zastupljenost u vrtu određena je njihova namjena.

\section{REZULTATI I RASPRAVA}

Iz tablice 1 vidljivo je da se u vrtovima TIP 1 nalazilo ukupno 43 taksona iz 16 porodica, a u vrtovima TIP 2 osam taksona iz šest botaničkih porodica. S najvećim brojem taksona (10) bila je zastupljena porodica Asteraceae što ne čudi s obzirom da velik broj jednogodišnjih cvjetnih vrsta jednostavnih za održavanje pripada upravo navedenoj porodici. Slijedi ju porodica Apiaceae sa šest taksona što se može objasniti činjenicom da u tu porodicu spada velik broj povrtnih, ali i začinskih vrsta dekorativnog izgleda listova, relativno jednostavnih za uzgoj i uporabu. Povrtnim vrstama bogata je i porodica Solanaceae, $\mathrm{u}$ vrtovima TIP 1 zastupljena $\mathrm{s}$ četiri taksona. Vrste porodice Solanaceae su zbog ukusnih plodova također atraktivne kod vrtlarenja s djecom. Vrt TIP 1 institucije 4 odudara brojnošću taksona u odnosu na vrtove drugih institucija. U njemu su od jedno- i dvogodišnjih vrsta u velikom udjelu zastupljene povrtne i začinske vrste te veći broj cvjetnih vrsta za razliku od 
ostalih vrtova TIP 1 i TIP 2 institucija koje očito ne poklanjaju dovoljnu pozornost okolišu oko svojih institucija, a zelene površine ne uključuju u odgojno-obrazovni proces.

Tablica 1. Zastupljenost jednogodišnjih i dvogodišnjih biljnih vrsta u vrtovima Tip 1 i Tip 2

Table 1 Representation of annuals and biennials in Gardens of Type 1 and Type 2

\begin{tabular}{|c|c|c|c|c|c|}
\hline PORODICA & VRSTA & \begin{tabular}{|c|} 
Broj Tip \\
1 vrta
\end{tabular} & $\begin{array}{c}\text { Broj } \\
\text { vrtova }^{\text {Tip } 1}\end{array}$ & $\begin{array}{l}\text { Broj Tip } \\
2 \text { vrta }\end{array}$ & \begin{tabular}{|c|} 
Broj \\
vrtova $^{\text {Tip } 2}$
\end{tabular} \\
\hline Alliaceae & $\begin{array}{l}\text { Allium cepa } \mathrm{L} . \\
\text { Allium schoenoprasum } \mathrm{L} \text {. }\end{array}$ & $\begin{array}{l}4 \\
4\end{array}$ & $\begin{array}{l}1 \\
1\end{array}$ & & \\
\hline Amaranthaceae & Celosia argentea $\mathrm{L}$. & 4 & 1 & & \\
\hline Apiaceae & $\begin{array}{l}\text { Anethum graveolens } \mathrm{L} . \\
\text { Apium graveolens } \mathrm{L} . \\
\text { Daucus carota } \mathrm{L} . \\
\text { Levisticum officinale } \mathrm{L} . \\
\text { Pastinaca sativa } \mathrm{L} . \\
\text { Petroselinum crispum Fuss. }\end{array}$ & $\begin{array}{l}4 \\
4 \\
4 \\
4 \\
4 \\
5\end{array}$ & $\begin{array}{l}1 \\
1 \\
1 \\
1 \\
1 \\
1\end{array}$ & 3 & 1 \\
\hline Asteraceae & $\begin{array}{l}\text { Bellis perennis } \mathrm{L} . \\
\text { Calendula officinalis } \mathrm{L} . \\
\text { Calistephus chinensis } \mathrm{L} . \\
\text { Centaurea cyanus } \mathrm{L} . \\
\text { Helianthus annuus } \mathrm{L} . \\
\text { Lactuca sativa } \mathrm{L} . \\
\text { Matricaria recutita } \mathrm{L} . \\
\text { Tagetes erecta } \mathrm{L} . \\
\text { Tagetes patula } \mathrm{L} . \\
\text { Zinnia elegans Jacq. }\end{array}$ & $\begin{array}{c}4,5,6 \\
4,5 \\
4 \\
4,6 \\
1,4,6 \\
4 \\
4 \\
4,6 \\
2,5 \\
4 \\
\end{array}$ & $\begin{array}{l}3 \\
2 \\
1 \\
1 \\
3 \\
1 \\
1 \\
2 \\
2 \\
1\end{array}$ & 3 & 1 \\
\hline Begoniaceae & Begonia semperflorens Hook. & $1,3,5$ & 3 & 1 & 1 \\
\hline Brassicaceae & $\begin{array}{l}\text { Brassica oleracea var. capitata } \mathrm{L} \text {. } \\
\text { Brassica oleracea var. botrytis } \mathrm{L} . \\
\text { Lobularia maritima } \mathrm{L} . \\
\text { Raphanus sativus } \mathrm{L} .\end{array}$ & $\begin{array}{l}4 \\
4 \\
4 \\
4\end{array}$ & $\begin{array}{l}1 \\
1 \\
1 \\
1\end{array}$ & & \\
\hline Campanulaceae & Lobelia erinus L. & 4 & 1 & & \\
\hline Caryophylaceae & Dianthus caryophyllus L. & 4,5 & 2 & & \\
\hline Chenopodiaceae & $\begin{array}{l}\text { Beta vulgaris var. Conditiva Alef. } \\
\text { Beta vulgaris subsp. vulgaris var. } \\
\text { vulgaris } \\
\text { Spinacea oleracea L. }\end{array}$ & $\begin{array}{r}4 \\
4 \\
4 \\
4\end{array}$ & $\begin{array}{l}1 \\
1 \\
1 \\
\end{array}$ & 1 & 1 \\
\hline Cucurbitaceae & $\begin{array}{l}\text { Cucurbita pepo var. clypeata } \\
\text { Cucurbita melopepo L. } \\
\text { Cucurbita pepo var.patissoniana } \\
\text { Filow. } \\
\text { Cucumis sativus L. } \\
\end{array}$ & $\begin{array}{l}4 \\
4 \\
4 \\
\end{array}$ & $\begin{array}{l}1 \\
1 \\
1 \\
\end{array}$ & & \\
\hline
\end{tabular}


Vesna Židovec i sur.: Vrtovi odgojno-obrazovnih institucija na području gradske četvrti Sesvete

\begin{tabular}{|c|c|c|c|c|c|}
\hline Fabaceae & $\begin{array}{l}\text { Phaseolus vulgaris } \mathrm{L} . \\
\text { Pisum sativum L. }\end{array}$ & $\begin{array}{l}4 \\
4 \\
\end{array}$ & $\begin{array}{l}1 \\
1\end{array}$ & 3 & 1 \\
\hline Lamiaceae & Ocimum basilicumL. & 4 & 1 & & \\
\hline Plumbaginaceae & Limonium sinuatum Mill. & 4 & 1 & & \\
\hline Primulaceae & Primula vulgaris L. & 4,5 & 2 & & \\
\hline Solanaceae & $\begin{array}{l}\text { Capsicum anuum L. } \\
\text { Solanum melongena } \mathrm{L} . \\
\text { Solanum lycopersicum } \mathrm{L} . \\
\text { Solanum lycopersicum var. } \\
\text { cerasiforme Dunal }\end{array}$ & $\begin{array}{l}4 \\
4 \\
4 \\
4\end{array}$ & $\begin{array}{l}1 \\
1 \\
1 \\
1\end{array}$ & & \\
\hline Violaceae & \begin{tabular}{|l} 
Viola odorata $\mathrm{L}$. \\
Viola $\times$ wittrockiana Gams.
\end{tabular} & $\begin{array}{c}3,5 \\
4,5,6\end{array}$ & $\begin{array}{l}2 \\
3\end{array}$ & $\begin{array}{l}1 \\
3\end{array}$ & $\begin{array}{l}1 \\
1\end{array}$ \\
\hline $\begin{array}{l}\text { Ukupan br. } \\
\text { taksona: }\end{array}$ & 42 & 43 & & 8 & \\
\hline $\begin{array}{l}\text { Ukupan br. } \\
\text { porodica: }\end{array}$ & 15 & & & & \\
\hline
\end{tabular}

Najzastupljenije vrste su Bellis perennis, tratinčica, koja je prisutna gotovo u svakom vrtu, bio on predškolski, školski ili kućni; Helianthus annuus, suncokret; Begonia semperflorens, begonija i Viola $\times$ wittrockiana, maćuhica. Iduće najbrojnije vrste su Calendula officinalis (neven), Dianthus caryophyllus (klinček), Tagetes erecta (kadifica visoka), Tagetes patula (kadifica niska) i Viola odorata (ljubičica).

Iz tablice 2 vidljivo je da je u vrtovima odgojno-obrazovnih institucija na području gradske četvrti Sesvete bilo zastupljeno ukupno 16 biljnih taksona iz 12 botaničkih porodica. U vrtovima TIP 1 evidentirano je 13 taksona, a u vrtovima TIP 2 njih sedam. Porodica predstavljena s najviše taksona (3) je porodica Lamiaceae. Ujedno, lavanda je uz čuvarkuću i ružu, vrsta koja je prisutna u najvećem broju vrtova (njih 3 od ukupno 10 obuhvaćenih ovim istraživanjem).

Iz tablice broj 3 vidljivo je da je u vrtovima TIP 1 i TIP 2 pronađeno ukupno 22 taksona grmlja iz 13 botaničkih porodica. U vrtovima TIP 1 bilo je 13 taksona, a u vrtovima TIP 2 njih 18. Porodica s najvećim brojem taksona bila je Rosaceae, slijede Cupressaceae i Oleaceae. Vrste Buxus sempervirens, Chamaecyparis lawsoniana i Prunus laurocerasus bile su pronađene u čak pet od ukupno 10 inventariziranih vrtova. Sve inventarizirane svojte grmova, osim jedne (lijeska), bile su isključivo ukrasnog karaktera te su prevladavale vazdazelene u odnosu na listopadne svojte (sedam). 
Vesna Židovec i sur.: Vrtovi odgojno-obrazovnih institucija na području gradske četvrti Sesvete

Tablica 2. Zastupljenost trajnica i geofita u vrtovima Tip 1 i Tip 2

Table 2 Representation of perennials in Gardens of Type 1 and Type 2

\begin{tabular}{|c|c|c|c|c|c|}
\hline PORODICA & VRSTA & $\begin{array}{c}\text { Broj Tip } \\
1 \text { vrta } \\
\end{array}$ & $\begin{array}{c}\text { Broj } \\
\text { vrtova }^{\text {Tip } 1}\end{array}$ & $\begin{array}{c}\text { Broj Tip } \\
2 \text { vrta } \\
\end{array}$ & $\begin{array}{c}\text { Broj } \\
\text { vrtova }^{\text {Tip } 2}\end{array}$ \\
\hline Apocynaceae & Vinca minor $\mathrm{L}$. & 5 & 1 & & \\
\hline Asteraceae & $\begin{array}{l}\text { Achillea millefolium L. } \\
\text { Cichorium intybus L. } \\
\end{array}$ & 4 & 1 & 3 & 1 \\
\hline Brassicaceae & $\begin{array}{l}\text { Brassica oleracea } \\
\text { var.gongylodes L. }\end{array}$ & 4 & 1 & & \\
\hline Cannaceae & Canna indica $\mathrm{L}$. & & & 3 & 1 \\
\hline Caryophyllaceae & Gypsophila sp. . & 4 & 1 & & \\
\hline Crassulaceae & Sempervivum tectorum L. & 4,5 & 2 & 3 & 1 \\
\hline Geraniaceae & Pelargonium peltatum L. & 3 & 1 & & \\
\hline Iridaceae & Iris germanica L. & 5 & 1 & 1 & 1 \\
\hline Lamiaceae & $\begin{array}{l}\text { Lavandula officinalis } \mathrm{L} \text {. } \\
\text { Salvia officinalis L. } \\
\text { Stachys lanata L. } \\
\end{array}$ & $\begin{array}{c}1,6 \\
5 \\
4,5 \\
\end{array}$ & $\begin{array}{l}2 \\
1 \\
2 \\
\end{array}$ & 3 & 1 \\
\hline Liliaceae & Lilium regale $\mathrm{L}$. & & & 4 & 1 \\
\hline Primulaceae & Primula vulgaris $\mathrm{L}$. & 4,5 & 2 & & \\
\hline Rosaceae & $\begin{array}{l}\text { Fragaria sp. } \\
\text { Rosa } \text { spp. }\end{array}$ & $\begin{array}{c}5 \\
4,5 \\
\end{array}$ & $\begin{array}{l}1 \\
2 \\
\end{array}$ & 4 & 1 \\
\hline Ukupan br. taksona: & 16 & 13 & & 7 & \\
\hline Ukupan br. porodica: & 12 & & & & \\
\hline
\end{tabular}

Tablica 3. Zastupljenost grmlja u vrtovima Tip 1 i Tip 2

Table 3 Representation of shrubs in Gardens of Type 1 and Type 2

\begin{tabular}{|c|c|c|c|c|c|}
\hline PORODICA & VRSTA & $\begin{array}{c}\text { Broj Tip } \\
1 \text { vrta }\end{array}$ & $\begin{array}{c}\text { Broj } \\
\text { vrtova }^{\text {Tip } 1}\end{array}$ & $\begin{array}{c}\text { Broj Tip } \\
2 \text { vrta }\end{array}$ & $\begin{array}{c}\text { Broj } \\
\text { vrtova }^{\text {Tip 2 }}\end{array}$ \\
\hline Aquifoliaceae & Ilex aquifolium L. & & & 1 & 1 \\
\hline Adoxaceae & Viburnum rhytidophyllum Hemsl. & & & 2 & 1 \\
\hline Betulaceae & Corylus avellana $\mathrm{L}$. & & & 2 & 1 \\
\hline Berberidaceae & Mahonia aquifolium Nutt. & & & 1 & 1 \\
\hline Buxaceae & Buxus sempervirens L. & $2,3,4,6$ & 4 & 4 & 1 \\
\hline Caprifoliaceae & Lonicera pileata Oliv. & & & 1,2 & 2 \\
\hline Celastraceae & $\begin{array}{l}\text { Euonymus japonicus Thunb. } \\
\text { Euonymus fortuneii 'Emerald n } \\
\text { Gold' }\end{array}$ & 5 & 1 & 1 & 1 \\
\hline Cupressaceae & $\begin{array}{l}\text { Chamaecyparis lawsoniana Parl. } \\
\text { Juniperus horizontalis L. } \\
\text { Thuja occidentalis L. } \\
\end{array}$ & $\begin{array}{c}1 \\
1 \\
4,5 \\
\end{array}$ & $\begin{array}{l}1 \\
1 \\
2\end{array}$ & $\begin{array}{c}1,2,3,4 \\
1\end{array}$ & $\begin{array}{l}4 \\
1\end{array}$ \\
\hline
\end{tabular}


Vesna Židovec i sur.: Vrtovi odgojno-obrazovnih institucija na području gradske četvrti Sesvete

\begin{tabular}{|c|c|c|c|c|c|}
\hline Hydrangeaceae & Philadelphus coronarius L. & 1 & 1 & 2,3 & 2 \\
\hline Lamiaceae & Rosmarinus officinalis L. & 4,6 & 2 & & \\
\hline Oleaceae & $\begin{array}{l}\text { Forsythia } \times \text { intermedia Thunb. } \\
\text { Ligustrum vulgare L. } \\
\text { Syringa vulgaris L. }\end{array}$ & 3,4 & 2 & 1,2 & 2 \\
\hline Paeoniaceae & Paeonia officinalis L. & 4 & 1 & 1 & 1 \\
\hline Rosaceae & $\begin{array}{l}\text { Cotoneaster dammeri C. K. Scheid } \\
\text { Prunus laurocerasus } \mathrm{L} . \\
\text { Prunus laurocerasus } \\
\text { 'Schipkaensis' L. } \\
\text { Spiraea bumalda 'Anthony } \\
\text { Waterer' Burv } \\
\text { Spiraea } \times \text { vanhouteii (Briot) Zabel }\end{array}$ & $\begin{array}{c}4 \\
1,4,6 \\
4\end{array}$ & $\begin{array}{l}1 \\
3 \\
1\end{array}$ & $\begin{array}{c}2,4 \\
2,3 \\
2 \\
1,2 \\
3 \\
\end{array}$ & $\begin{array}{l}2 \\
2 \\
1\end{array}$ \\
\hline $\begin{array}{l}\text { Ukupan br. } \\
\text { taksona: }\end{array}$ & 22 & 13 & & 18 & \\
\hline $\begin{array}{l}\text { Ukupan br. } \\
\text { porodica: }\end{array}$ & 13 & & & & \\
\hline
\end{tabular}

Iz tablice 4. vidljivo je da je u vrtovima obuhvaćenim ovim istraživanjem evidentirano ukupno 38 taksona drveća iz 19 porodica. U vrtovima TIPa 1 bilo je 25 taksona iz 13 porodica, a u vrtovima TIPa 226 . Porodice s najviše taksona bile su Pinaceae (7), Aceraceae (6) i Rosaceae (6). Taksoni koji su bili zastupljeni u najvećem broju vrtova su Betula pendula (6), Picea abies (5) i Malus domestica (5). U vrtovima TIP 1 najzastupljenije su vrste drveća iz porodice Aceraceae, Acer pseudoplatanus (gorski javor) i Acer saccharinum (javor šećerac), te iz porodice Pinaceae vrsta Picea pungens (srebrna smreka). U vrtovima TIP 2 najzastupljenije vrste su Betula pendula (breza), Malus domestica (jabuka) i Picea abies (smreka).

U svim vrtovima TIPa 2 obuhvaćenim ovim istraživanjem nalazila se barem jedna voćna vrsta, dok su u slučaju vrtova TIPa 1 samo u tri evidentirane voćne vrste. Vrt TIPa 1 s najviše voćnih vrsta (4) je vrt 2, a vrt TIPa 2, također s tri voćne vrste je vrt 1 , dok su u vrtu 4 zabilježene dvije voćne vrste. Stječe se dojam da se navedene vrste $u$ vrtovima nalaze slučajno. 
Vesna Židovec i sur.: Vrtovi odgojno-obrazovnih institucija na području gradske četvrti Sesvete

Tablica 4. Zastupljenost drveća u vrtovima Tip 1 i Tip 2

Table 4 Representation of trees in Gardens of Type 1 and Type 2

\begin{tabular}{|c|c|c|c|c|c|}
\hline PORODICA & VRSTA & \begin{tabular}{|c|} 
Broj Tip \\
1 vrta \\
\end{tabular} & $\begin{array}{c}\text { Broj } \\
\text { vrtova }^{\text {Tip } 1}\end{array}$ & \begin{tabular}{|c|} 
Broj Tip \\
2 vrta \\
\end{tabular} & \begin{tabular}{|c|} 
Broj \\
vrtova $^{\text {Tip } 2}$
\end{tabular} \\
\hline Aceraceae & $\begin{array}{l}\text { Acer campestre L. } \\
\text { Acer negundo L. } \\
\text { Acer palmatum } \\
\text { var. atropurpureum Thunb. } \\
\text { Acer platanoides 'Crimson } \\
\text { King' } \\
\text { Acer pseudoplatanus L. } \\
\text { Acer sacharinum L. } \\
\end{array}$ & $\begin{array}{c}4 \\
3 \\
1,6 \\
1,3 \\
1,4,6 \\
1,3,5\end{array}$ & $\begin{array}{l}1 \\
1 \\
2 \\
\\
2 \\
3 \\
3\end{array}$ & $\begin{array}{l}1 \\
4\end{array}$ & $\begin{array}{l}1 \\
1\end{array}$ \\
\hline Altingiaceae & Liquidambar stiraciflua L. & 1 & 1 & 3 & 1 \\
\hline Betualceae & Betula pendula Roth. & 1,6 & 2 & $1,2,3,4$ & 4 \\
\hline Bignoniaceae & Catalpa bignonioides Walter & & & 3 & 1 \\
\hline Fagaceae & $\begin{array}{l}\text { Quercus robur 'Fastegiata' L. } \\
\text { Quercus rubra L. }\end{array}$ & & & $\begin{array}{l}2 \\
1 \\
\end{array}$ & $\begin{array}{l}1 \\
1 \\
\end{array}$ \\
\hline Ginkgoaceae & Ginkgo biloba L. & & & 4 & 1 \\
\hline Hippocastanaceae & Aesculus hypocastanum L. & 5 & 1 & & \\
\hline Juglandaceae & Juglans regia $\mathrm{L}$. & 1,2 & 2 & & \\
\hline Magnoliaceae & $\begin{array}{l}\text { Liriodendron tulipifera } \mathrm{L} \text {. } \\
\text { Magnolia soulangeana } \\
\text { Thieb-Bern. }\end{array}$ & 1 & 1 & $\begin{array}{l}2 \\
2\end{array}$ & $\begin{array}{l}1 \\
1\end{array}$ \\
\hline Malvaceae & Tilia platyphyllos L. & & & 2 & 1 \\
\hline Oleaceae & Fraxinus excelsior $\mathrm{L}$. & 4 & 1 & $2,3,4$ & 3 \\
\hline Pinaceae & $\begin{array}{l}\text { Abies concolor L. } \\
\text { Larix decidua } \text { Mill. } \\
\text { Picea abies L. } \\
\text { Picea pungens Engelm. } \\
\text { Picea pungens 'Glauca' } \\
\text { Pinus sp. } \\
\text { Pinus wallichiana A. B. Jacks. } \\
\end{array}$ & $\begin{array}{c}5 \\
1,6 \\
1,4,5 \\
1,6 \\
2,5\end{array}$ & $\begin{array}{l}1 \\
2 \\
3 \\
2 \\
2\end{array}$ & $\begin{array}{c}2 \\
1,2,4\end{array}$ & $\begin{array}{l}1 \\
3\end{array}$ \\
\hline Platanaceae & Platanus occidentalis $\mathrm{L}$. & & & 2 & 1 \\
\hline Rosaceae & $\begin{array}{l}\text { Malus domestica } \text { Borkh. } \\
\text { Photinia fraseri 'Red Robin' } \\
\text { Lindl. } \\
\text { Prunus avium } \text { L. } \\
\text { Prunus cerasifera 'Nigra' } \\
\text { Prunus domestica L. } \\
\text { Pyrus } \text { sp. } \\
\end{array}$ & $\begin{array}{c}2,4 \\
1 \\
4 \\
2\end{array}$ & $\begin{array}{l}2 \\
1 \\
1 \\
1\end{array}$ & $\begin{array}{c}1,2,4 \\
1 \\
2,3 \\
1,4\end{array}$ & $\begin{array}{l}3 \\
1 \\
2 \\
2\end{array}$ \\
\hline Salicaceae & $\begin{array}{l}\text { Populus alba } \mathrm{L} \text {. } \\
\text { Populus nigra var. italica }\end{array}$ & & & $\begin{array}{l}4 \\
2 \\
\end{array}$ & $\begin{array}{l}1 \\
1\end{array}$ \\
\hline Sapindaceae & Koelreuteria paniculata Laxm. & 4 & 1 & & \\
\hline
\end{tabular}


Vesna Židovec i sur.: Vrtovi odgojno-obrazovnih institucija na području gradske četvrti Sesvete

\begin{tabular}{|l|l|c|c|c|c|}
\hline Simaroubaceae & Ailanthus altissima Mill. & 6 & 1 & 2 & 1 \\
\hline Taxaceae & Taxus baccata L. & 4 & 1 & & \\
\hline Tiliaceae & Tilia cordata Mill. & 4 & 1 & 1,3 & 2 \\
\hline Ukupan br. taksona: & 38 & 25 & & 26 & \\
\hline $\begin{array}{l}\text { Ukupan br. } \\
\text { porodica: }\end{array}$ & 19 & \multicolumn{5}{l}{} \\
\cline { 1 - 3 } & \multicolumn{1}{|l|}{19} &
\end{tabular}

Iz Grafa 1. uočljivo je da je zastupljenost jednogodišnjih i dvogodišnjih biljnih vrsta u vrtovima TIPa 1 veća za $32 \%$ u odnosu na vrtove TIPa 2 , zastupljenost trajnica i geofita u vrtovima TIPa 1 je za $6 \%$ manja, grmlja za $12 \%$ manja, a drveća za $14 \%$ manja u odnosu na vrtove TIPa 2 . Najviše se primjenjuju drvenaste vrste, zatim grmlje, trajnice i geofita u manjoj mjeri, a najmanje je jedno- i dvogodišnjih vrsta. Znatno veća primjena jedno- i dvogodišnjih vrsta kod TIPa 1 proizlazi iz primjene istih u jednom objektu TIPa 1 (4), jedinom u kojem se sustavno uređuju povrtnjak i cvjetnjak.

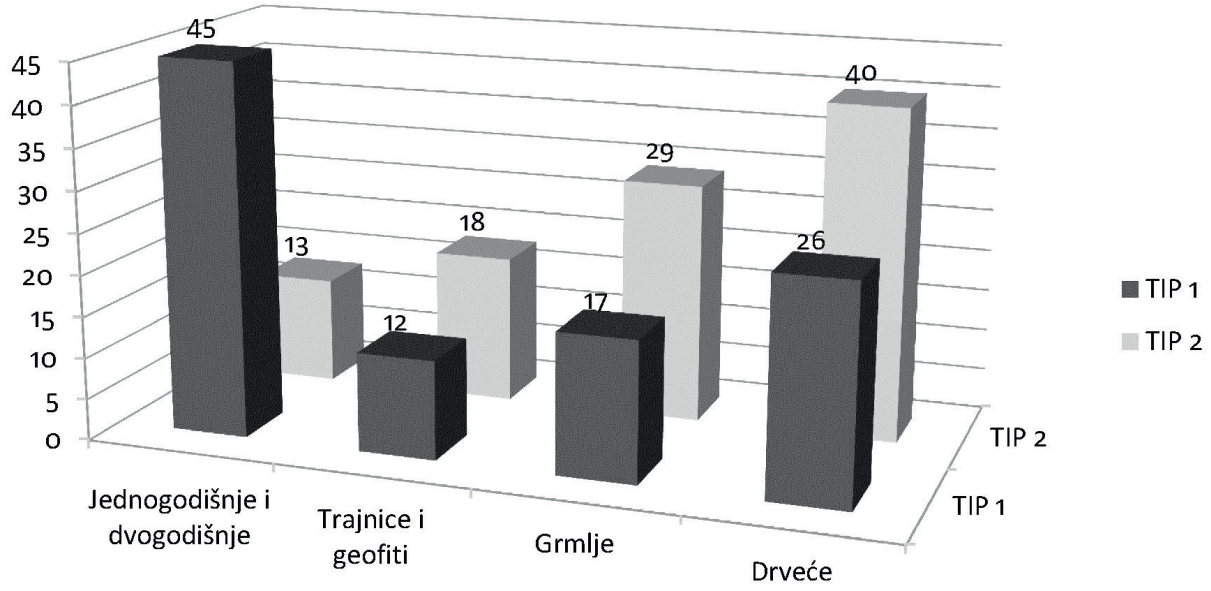

Graf 1. Odnos zastupljenosti biljnih vrsta u vrtovima Tip 1 i Tip 2 u\%-cima

Graph 1 The ratio of plant species to species Type 1 and Type $2 \mathrm{in} \%$

Prema rezultatima dobivenim ovim istraživanjem vidi se da vrtovi uz predškolske i osnovnoškolske institucije na području gradske četvrti Sesvete odudaraju od tradicionalnih kućnih vrtova ruralnih i suburbanih područja kod kojih je najveći broj jedno- i dvogodišnjih cvjetnih vrsta, trajnica i geofita, dok je broj grmova, a naročito stabala znatno manji (Šojlevski, 1976.). Vrtovi ovih ustanova odudaraju i od preporuka o odabiru biljnih vrsta za školske vrtove 
Vesna Židovec i sur.: Vrtovi odgojno-obrazovnih institucija na području gradske četvrti Sesvete

(Trstenjak, 1883.). Od biljnih vrsta koje su se nekad nalazile u školskim vrtovima determinirano je svega nekoliko, a to su jabuka, ruža i nešto povrtnih vrsta. To upućuje na činjenicu da se zeleni prostori oko istraživanih odgojnoobrazovnih institucija ne koriste na pravi način.

Kod odabira drvenastih vrsta pojavljuju se pak otrovne i alergene vrste. Ovim istraživanjem utvrđena je primjena ukupno 15 otrovnih i alergenih vrsta u vrtovima odgojno-obrazovnih institucija na području gradske četvrti Sesvete. Učestalu primjenu: 15 različitih otrovnih i 17 alergenih vrsta na sedam od ukupno devet analiziranih lokacija na području grada Samobora potvrdile su i Vlahović i Karlović (2013.) te Perinčić i sur. (2014.) osam otrovnih vrsta u 12 dvorišta vrtića i škola na području Zadra.

Prema Vlahović i Karlović (2013.), Douglas (2005) procjenjuje da je 3,5\% svih trovanja uzrokovano otrovnim biljkama. Većina tih trovanja javlja se kod djece školske dobi ili čak mlađima. Fančovičová i Prokop (2011.) ističu da je dječje znanje o biljnim vrstama ograničeno te da bi trebalo posvetiti više pažnje edukaciji djece. Tu činjenicu potvrđuje Lucas (2006.) koji navodi da se u 55\%, od ukupno analiziranih slučajeva trovanja školske djece, radi o konzumaciji otrovnih biljaka zbog pogrešne identifikacije. Kod projektiranja i uređenja dvorišta škola i dječjih vrtića potrebno je dati prednost odabiru vrsta koje nisu toksične, alergene ili trnovite. Dekorativnost i oblikovanje su u ovom slučaju na drugom mjestu.

\section{ZAKLJUČCI}

Iz navedenog istraživanja može se zaključiti da je u vrtovima TIPa 1 brojnost jednogodišnjih i dvogodišnjih vrsta iznosila 57, trajnica i geofita 16, grmlja 24 i drveća 39, dok je u vrtovima TIPa 2 brojnost jednogodišnjih i dvogodišnjih vrsta iznosila 8, trajnica i geofita 7, grmlja 27 i drveća 39. Nažalost, samo je jedan vrt TIPa 1 imao svoj povrtnjak, ograđeni dio sa stazama za prolaz između gredica, donekle onako kako bi trebalo težiti da svi vrtovi, i TIPa 1 i TIPa 2, imaju na svojoj površini. Također, zabilježena je primjena otrovnih i alergenih vrsta u vrtovima TIP 1 i TIP 2 . Ravnatelji, stručne službe i odgovorne osobe istraživanih ustanova, navode nedostatak financijskih sredstava kao uzrok za zatečeno stanje. Vrtovi uz predškolske i školske ustanove na području gradske četvrti Sesvete ne odražavaju tradicionalne vrtove sesvetskog prigorja i uglavnom su loše održavani. 
Vesna Židovec i sur.: Vrtovi odgojno-obrazovnih institucija na području gradske četvrti Sesvete

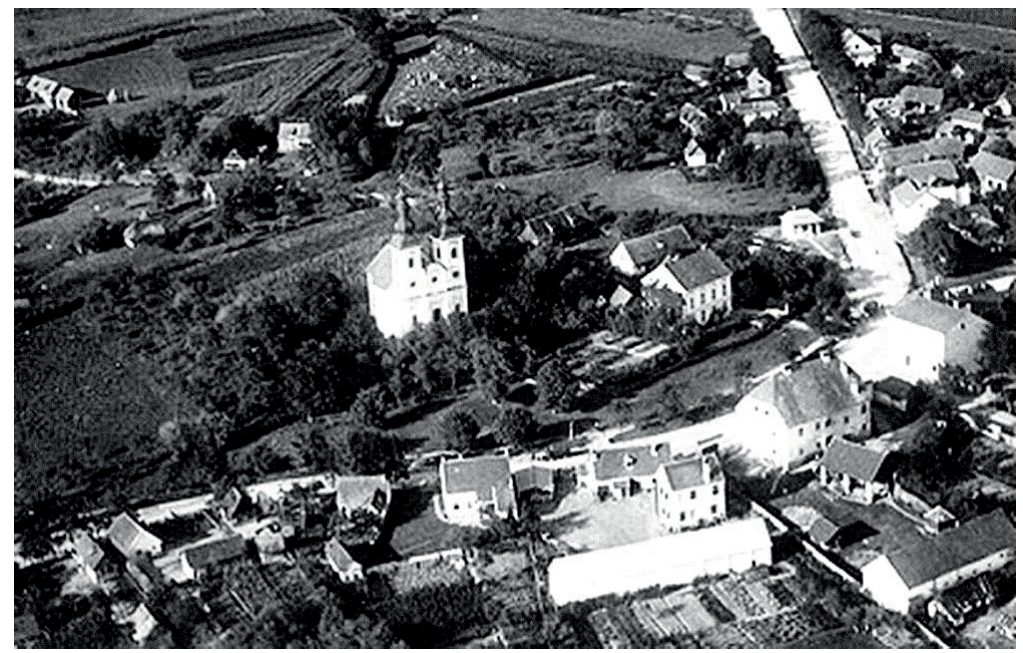

Slika 1. Centar Sesveta nekad

Photo 1 Sesvete centre ago

(http://www.sesvete-danas.hr/i-kutak/sesvete-nekad/ sesvete-nekad-one-moment-in-time-album-br-1-246)

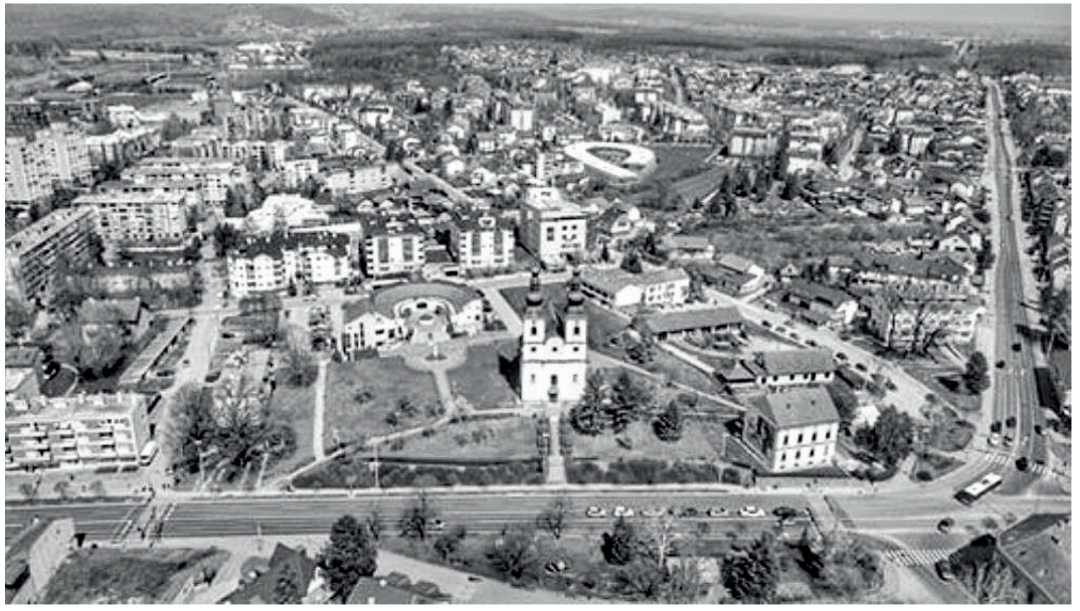

Slika 2. Centar Sesveta danas

Photo 2 Sesvete novadays

(http://www.sesvete-danas.hr/vijesti/proljetni-pogled-na-sesvete-iz-zraka-7805) 
Vesna Židovec i sur.: Vrtovi odgojno-obrazovnih institucija na području gradske četvrti Sesvete

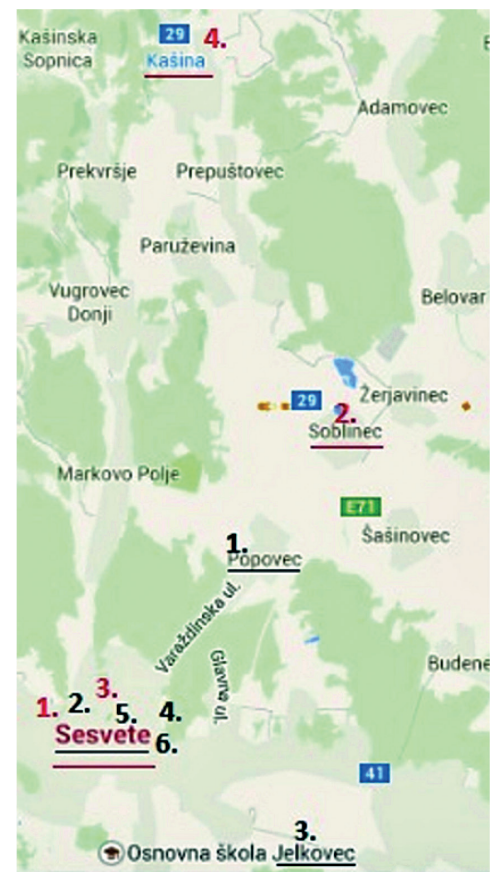

Slika 3. Lokacija istraživanih vrtova (izvor: https:www.google.hr/maps/

Photo 3 Locations of gardens inventoried

LEGENDA: / LEGEND:

1. 2. 3. 4. 5. 6. - Tip 1 (predškolski vrt) / Type 1 (preschool gardens)

1. 2. 3. 4. - Tip 2 (školski vrt) / Type 2 (school gardens)

\section{LITERATURA}

1. Barnicle, T., Stoelzle Midden, K. (2003.): The effects of a horticultural activity program on the psychological well-being of older people in a long-term care facility. Hort Technology 13: 81-5.

2. Blair, D., Giesecke, C., Sherman, S. (1991.): A dietary, social, and economic evaluation of the Philadelphia urban gardening project. J Nutrition Education 23: 161-7.

3. Bunn, D.E. (1986.): Group cohesiveness is enhanced as children engage in plant stimulated discovery activities. Journal of Therapeutic Horticulture 1: 37-43. 
Vesna Židovec i sur.: Vrtovi odgojno-obrazovnih institucija na području gradske četvrti Sesvete

4. Butorac, M., Šimleša, D. (2007.): Zelena srca gradova važnost vrtova i perivoja u urbanim područjima. Društvena istraživanja 6(92): 1081-1101

5. Cooper Marcus, C., Barnes, M. (1999.): Healing gardens: Therapeutic benefits and design recommendations. London, Chichester, UK: J. Wiley.

6. Davies, Z.G., Fuller, R.A., Loram, A.; Irvine, K.N.; Sims, V.; Gaston, K.J. (2009.): A national scale inventory of resource provision for biodiversity within domestic gardens. Biological Conservation 42: 761-771

7. de Vries, S., Verheij, R.A., Groenewegen, P.P., Spreeuwenberg, P. (2003.): Natural environments - healthy environments? An exploratory analysis of the relationship between green space and health. Environemnt and Planning A 35: 1717-1731.

8. Domac, R. (2002.): Flora Hrvatske: priručnik za određivanje bilja. Zagreb, Školska knjiga

9. Douglas, S.M. (2005.) Poisonous plants (online). The Connecticut Agricultural Experiment Station Online < www.ct.gov/caes > Pristupljeno 06. travnja 2012.

10. Dujmović, J. (2016.): Terapijski vrtovi i terapijska hortikultura kao intervencija u zdravstvu. Socijalna psihijatrija 44: 14-21

11. Erhardt W., Gotz E., Bodeker N., Seybold S. (2014.): Zander - Handworterbuch der Pflanzennamen. Eugen Ulmer GmbH \& Co., Stuttgart

12. Fančovičová, J., Prokop, P. (2011.): Children's Ability to Recognise Toxic and Non-Toxic Fruits. Eurasia Journal of Mathematics, Science \& Technology Education, 7(2): 115-120.

13. Feenstra, G., McGrew, S., Campbell, D. (1999.): Entrepreneurial community gardens: Growing food, skills, jobs and communities. Davis CA: University of CA - Davis.

14. Fuller, R.A., Irvine, K.N., Devine-Wright, P., Warren, P.H., Gaston, K.J. (2007.): Psychological benefits of green space increase with biodiversity. Biology Letters 3, 390-394.

15. Galindo, M., Rodrieguez, J. (2001.): Environmental aesthetics and psychological well-being: Relationships between preference judgements for urban landscapes and other relevant affective responses. Psychology in Spain 4: 13-27.

16. Grad Zagreb - https://www.zagreb.hr/en/gradska-cetvrt-sesvete/163 pristupljeno 05.12.2018.

17. Hartig, T., Mang, M., Evans, G.W. (1991.): Restorative effects of natural environment experiences. Environment and Behaviour 23, 3-26. 
Vesna Židovec i sur.: Vrtovi odgojno-obrazovnih institucija na području gradske četvrti Sesvete

18. Hartig, T. (2003.): Restorative environments: Guest editor's introduction. Environment Behavior 33: 475-9.

19. Herzog, T.R., Black, A.M., Fountaine, K.A., Knotts, D.J. (1997.): Reflection and attentional recovery as distinctive benefits of restorative environments. Journal of Environmental Psychology 17, 165-170.

20. Idžojtić M. (2009.): Dendrologija - list. Sveučilište u Zagrebu, Šumarski fakultet, Zagreb

21. Irvine, K.N., Warber, S.L. (2002.): Greening healthcare: practicing as if the natural environment really mattered. Alternative Therapies in Health and Medicine 8, 76-83

22. Jarrott, S.E., Kwack, R.H., Relf, D. (2002.): An observational assessment of a dementia-specific horticultural therapy program. HortTechnology 12: 402-10.

23. Kaplan, R., Kaplan, S. (1989.): The Experience of Nature: A Psychological Perspective. Cambridge University Press, Cambridge.

24. Kaplan, R. (2001.): The nature of the view from home: Psychological benefits. Environment Behavavior 33: 507-42.

25. Katcher, A., Beck, A. (1987.): Health and caring for living things. Anthrozoos $1,175-183$.

26. Kuo, F.E. (2001.) Coping with poverty: impacts of environment and attention in the inner city. Environment and Behaviour 33, 5-34.

27. Kuo, F.E., Sullivan, W.C. (2001.): Environment and crime in the inner city. Does vegetation reduce crime? Environment and Behaviour 33, 343-367.

28. Kuo, F.E., Bacaicoa, M., Sullivan, W.C. (1998.): Transforming inner-city landscapes. Trees, sense of safety and preference. Environment Behav 30: 2859.

29. Kweon, B.S., Sullivan, W.C., Wiley, A.R. (1998.): Green common spaces and the social integration of inner-city older adults. Environmental Behavior 30: 832-58.

30. Langer, E., Rodin, J. (1976.): The effects of choice and enhanced personal response for the aged: A field experiment in an institutional setting. Journal of Personality Social Psychology 34: 191-8.

31. Leather, P., Pyrgas, M., Beale, D., Lawrence, C. (1998.): Windows in the workplace. Environment and Behaviour 30, 739-763.

32. Lucas, G. N. (2006.): A hospital based prospective study of acute childhood poisoning. Sri Lanka Journal of Child Health, 35: 12-19. 
Vesna Židovec i sur.: Vrtovi odgojno-obrazovnih institucija na području gradske četvrti Sesvete

33. Maas, J., Verheij, R.A., Groenewegen, P.P., de Vries, S., Spreeuwenberg, P. (2006.): Green space, urbanity, and health: how strong is the relation? Journal of Epidemiology and Community Health 60, 587-592.

34. Macintyre, S., Ellaway, A., Hiscock, R., Kearns, A., Der, G., McKay, L. (2003.): What features of the home and the area might help to explain observed relationships between housing tenure and health: evidence from the west of Scotland. Health and Place 9, 207-218.

35. Maller, C., Townsend, M., Pryor, A., Brown, P., St. Leger, L. (2005.): Healthy nature healthy people: 'contact with nature' as an upstream health promotion intervention for populations. Health Promotion International 21, 45-54.

36. Mooney, P.F., Milstein, S.L. (1994.): Assessing the benefits of a therapeutic horticulture program for seniors in intermediate care. U: Francis M, Lindsay P, Stone RJ, eds. The healing dimension of people-plant relations: Proceedings of a research symposium. Los Angeles: University of CA.

37. Moore, E.O. (1981.): A prison environment's effect on health care service demands. Journal of Environmental Systems 11, 17-34.

38. Moore, B. (1989.): Growing with gardening: A twelve-month guide for therapy, recreation, and education. Raleigh: Chapel Hill, University of North Carolina Press.

39. Muehlhoff, E., Boutrif, E. (2010.): A new deal for school gardens. FAO

40. Munjiza, E. (2003.): Pedagogijska funkcija školskih vrtova. Velika Kopanica, Teka d.o.o.

41. Namazi, K.H., Haynes, S.R. (1994.): Sensory stimuli reminiscence for patients with Alzheimer's disease: Relevance and implications. Clin Gerontol 14: 29-45.

42. Parsons, R., Tassinary, L.G., Ulrich, R.S., Hebl, M.R., Grossman-Alexander, M. (1998.): The view from the road: implications for stress recovery and immunisation. Journal of Environmental Psychology 18, 113-140.

43. Perinčić, B., Milović, M., Radoš, D. (2014.): Otrovne biljne vrste u dvorištima škola i dječjih vrtića grada Zadra. 49. hrvatski i 9. međunarodni simpozij agronoma - Zbornik sažetaka/Marić, S., Lončarić, Z.(ur.) - Dubrovnik: Poljoprivredni fakultet Sveučilišta Josipa Jurja Strossmayera u Osijeku, 320-32

44. Perrins-Margalis, N., Rugletic, J., Schepis, N., Stepanski, H., Walsh, M. (2000.): The immediate effects of group-based horticulture on the quality of life of persons with chronic mental illness. Occupational Therapy and Mental Health 16: 15-30.

45. Relf, P.D., McDaniel, A., Butterfield, B. (1992.): Attitudes toward plants and gardening. HortTechnology 2: 201-4. 
Vesna Židovec i sur.: Vrtovi odgojno-obrazovnih institucija na području gradske četvrti Sesvete

46. Relf, P.D. (1978.): Horticulture as a recreational activity. Am Health Care Association Journal 4: 68-71.

47. Rodiek, S. (2002.): Influence of an outdoor garden on mood and stress in older persons, J Therapeutic Horticulture 13: 13-21.

48. Schwab, E. (1877.): Školski vrt. Prinos za riešenje zadatka o javnom odgoju. Zagreb. Litografički i tipografički zavod C.Albrechta.

49. Skulj, A. (1954): Školski vrt. Ljubljana. Državna založba Slovenije.

50. Stigsdotter, U.A., Grahn, P. (2004.): A garden at your workplace may reduce stress, In: Dilani, A. (Ed.), Design and Health III - Health Promotion through Environmental Design Research Centre for Design and Health, Stockholm, pp. 147-157.

51. Stilgoe, J.R. (2001.): Gone barefoot lately? American Journal of Preventive Medicine 20: 243-244.

52. Sullivan, W.C., Kuo, F.E., DePooter, S.F. (2004.): The fruit of urban nature: vital neighbourhood spaces. Environment and Behaviour 36, 678-700.

53. Šišić, B. (2011.): Autohtono zelenilo - čimbnik mjesnog identiteta u Dubrovačkom kraju. Klesarstvo i graditeljstvo, Pučišća, br. 1-2

54. Šojlevski, D. (1976.): Makedonski kućni vrt kao jedan od elemenata za suvremeno oblikovanje parkova. Doktorska disertacija Fakultet poljoprivrednih znanosti Sveučilišta u Zagrebu, Zagreb, 1976.

55. Takano, T., Nakamura, K., Watanabe, M. (2002.): Urban residential environments and senior citizens longevity in megacity areas: the importance of walkable green spaces. Journal of Epidemiology and Community Health 56, 913-918.

56. Taylor, A.F., Kuo, F.E., Sullivan, W.C. (2001.): Coping with ADD: The surprising connection to green play settings. Environment Behav 33: 54-77.

57. Trstenjak, D. (1883.): Školski vrt na selu. Nakladom Hrv. pedagogijskoknjiževnoga sbora. Zagreb

58. Ulrich, R.S. (1984.): View through a window may influence recovery from surgery. Science 224, 420-421.

59. Ulrich, R,S,, Parsons, R. (1992.): Influences of passive experiences with plants on individual well-being and health. U: Relf, D. ur. The role of horticulture in human well-being and social development. Portland: Timber Press

60. Ulrich, R.S., Simons, R.F., Losito, B.D., Fiorito, E., Miles, M.A., Zelson, M. (1991.): Stress recovery during exposure to natural and urban environments. J Environment Psychology 11: 201-30. 
Vesna Židovec i sur.: Vrtovi odgojno-obrazovnih institucija na području gradske četvrti Sesvete

61. Vladimir, V. (1998.): Školski vrt kao čimbenik socijalizacije učenika. Diplomski rad. Sveučilište u Zagrebu, Agronomski fakultet.

62. Vlahović, I., Karlović, K. (2013.): Otrovne i alergene biljne vrste u školskim vrtovima grada Samobora. Agronomski glasnik 2-3: 107-115.

63. Waliczek, T.M., Mattson, R.H., Zajicek, J.M. (1996.): Benefits of community gardening to quality of life issues. J Environment Horticulture 14: 204-9.

64. Wells, N.M. (2000.): At home with nature: Effects of ,greenness“ on children's cognitive functioning. Environment Behav 32: 775-95.

65. Whitehous, S., Varni, J.W., Sei, M. (2001.): Evaluating a children's hospital garden environment: Utilization and consumer satisfaction. J Environment Psychology 21: 301-314.

66. Willets, H.C., Sperling, A. (1983.): The role of the therapeutic recreationist in assisting the oncology patient to cope. New York: Futura.

Adrese autora - Author's addresses:

Vesna Židovec, korespondent autor, e-mail: vzidovec@agr.hr

Tea Pirić,

Martina Skendrović Babojelić, Dubravka Dujmović Purgar

Sveučilište u Zagrebu Agronomski fakultet, Svetošimunska cesta 25, 10000

Zagreb, Hrvatska
Primljeno - Received

30.11.2018. 